\title{
Root elongation in tropical Eucalyptus plantations: effect of soil water content
}

\author{
Armel Thongo M'Bou ${ }^{1,3,4}$, Christophe JourdaN ${ }^{2}$, Philippe DelePorte ${ }^{1,2}$, Yann Nouvellon ${ }^{1,2}$, Laurent \\ SAINT-ANDRÉ ${ }^{2}$, Jean-Pierre BouILlET ${ }^{2}$, Fidèle MiALOUNDAMA ${ }^{3}$, André MABIALA $^{1}$, Daniel EPRON ${ }^{4 *}$ \\ ${ }^{1}$ Unité de Recherche sur la Productivité des Plantations Industrielles, BP 1291 Pointe-Noire, Congo \\ ${ }^{2}$ CIRAD, UPR Écosystèmes de Plantations, 34398, Montpellier, France \\ ${ }^{3}$ Université de Brazzaville, Faculté des Sciences, BP 69, Brazzaville, Congo \\ ${ }^{4}$ Nancy-Université - Université Henri Poincaré, UMR INRA UHP 1137 Ecologie et Ecophysiologie Forestières, Faculté des Sciences, BP 239, \\ 54506 Vandoeuvre les Nancy Cedex, France
}

(Received 25 February 2008; accepted 2 April 2008)

\begin{abstract}
-
- Sustainability of Eucalyptus plantations is often questioned in resource-limited environments, especially in areas characterized by soils with poor nutrient and water holding capacities. Yet, field-based observations of fine root dynamics in relation with the seasonality of rainfall are lacking.

- This study was undertaken on two Eucalyptus stands planted in the Kouilou Region (south-western Congo), which is characterized by a four-monthlong dry season. Fine root (less than $2 \mathrm{~mm}$ in diameter) dynamics were studied using rhizotron observations of root elongation in the field.

- Fine root elongation rates displayed a seasonal variation in the two stands, with higher elongation rates during the rainy season than during the dry season. Positive and significant correlations were found between fine root elongation rates and soil water content at all depths, but a better correlation was found with soil water content in the deep soil horizon than in the superficial horizons.

- These results suggest that the temporal variations in fine root elongation were related to the seasonality of rainfall, and they were probably associated with seasonal changes in tree water status, carbon assimilation and belowground allocation.
\end{abstract}

fine roots / growth / rhizotron / Eucalyptus / soil water content

Résumé - Élongation des racines dans les plantations tropicales d'Eucalyptus : effet du contenu en eau du sol.

- La question de la durabilité des plantations d'Eucalyptus est souvent posée dans les environnements où les ressources sont limitées, en particulier les zones où les sols ont une faible capacité à retenir l'eau et les nutriments et où la saison sèche est longue. Pourtant, les observations in situ de la dynamique racinaire en relation avec la saisonnalité des pluies sont inexistantes.

- Cette étude a été réalisée dans deux plantations d'Eucalyptus de la région du Kouilou dans le sud ouest du Congo, qui est caractérisée par quatre mois de saison sèche. La dynamique des racines fines (moins de $2 \mathrm{~mm}$ de diamètre) a été étudiée à l'aide de rhizotrons permettant d'observer l'élongation racinaire au champ.

- La vitesse d'élongation des racines fines montrait une variation saisonnière dans les deux plantations, avec des vitesses plus élevées en saison des pluies qu'en saison sèche. Des corrélations positives et significatives ont été trouvées entre la vitesse d'élongation des racines fines et la teneur en eau du sol à toutes les profondeurs, mais les meilleures corrélations ont été observées avec la teneur en eau des horizons profonds.

- Cela suggère que les variations temporelles de l'élongation des racines fines sont reliées à la saisonnalité des précipitations, et qu'elles sont associées aux changements saisonniers d'état hydrique des arbres, d'assimilation carbonée et d'allocation vers les parties souterraines.

racines fines / croissance / rhizotron / Eucalyptus / teneur en eau du sol

\section{INTRODUCTION}

Fine roots play a major role in water and nutrient uptake, and fine root production and turnover are important processes in the carbon flow and nutrient cycling of terrestrial ecosystems (Gill and Jackson, 2000; Laclau et al., 2004; Lauenroth and Gill, 2003; Tierney and Fahey, 2002; West et al., 2004). Despite its importance in the water, carbon and nutrient balance of the ecosystem, fewer studies have been made of root

\footnotetext{
*Corresponding author: daniel.epron@scbiol.uhp-nancy.fr
}

growth than of the aboveground growth of trees in the field, because of methodological difficulties (Vogt et al., 1998).

Most existing techniques used to measure fine root dynamics are controversial (De Ruijter et al., 1996; Hendricks et al., 2006; Vogt et al., 1998). They can be grouped into two main families. One includes destructive sampling methods relying on sequential soil coring, where root production is computed from seasonal changes in root biomass and necromass, or from root ingrowth into root-free soil cores (Hendricks et al., 2006; Neill, 1992; Van Praag et al., 1988). These methods are less labour intensive, but they come up against the problem of sample numbers, sampling periods and distinguishing between 
Table I. Description of the selected stands.

\begin{tabular}{cccccccc}
\hline $\begin{array}{c}\text { Stand } \\
\text { name }\end{array}$ & $\begin{array}{c}\text { Age } \\
(\text { months })\end{array}$ & $\begin{array}{c}\text { Stocking } \\
\left(\text { stem ha }^{-1}\right)\end{array}$ & $\begin{array}{c}\text { Mortality } \\
(\%)\end{array}$ & $\begin{array}{c}\text { Basal area } \\
\left(\mathrm{m}^{2} \mathrm{ha}^{-1}\right)\end{array}$ & $\begin{array}{c}\text { Average } \\
\text { height }(\mathrm{m})\end{array}$ & $\begin{array}{c}\text { Average } \\
\mathrm{CBH}(\mathrm{cm})\end{array}$ & $\begin{array}{c}\text { Number of } \\
\text { rhizotrons }\end{array}$ \\
\hline R99-11 & 9 & 820 & 0 & 1.5 & 1.40 & - & 6 \\
H98-02 & 24 & 700 & 19 & 4.3 & 11.30 & 30.97 \\
\hline
\end{tabular}

living and dead roots. The other family of techniques relies on direct observation of root elongation on large panes of glass (rhizotrons; Jourdan and Rey, 1997; Green et al., 2005; Sword, 1998) or on small-diameter transparent tubes inserted into the soil (minirhizotron, Hendrick and Pregitzer, 1993; 1996; Majdi et al., 2005). These visual methods enable quantitative and qualitative measurements of the root system (Vogt et al., 1998). As non-destructive methods of individual root observation, they can also be used to characterize root elongation, root lifespan, death and decomposition (De Ruijter et al., 1996; Lauenroth and Gill, 2003). However the main drawback of these methods remains the physical disturbance of the soil and the change in temperature and moisture at the window/soil interface as compared with bulk soil (De Ruijter et al., 1996; Vogt et al., 1998).

Better knowledge of fine root dynamics and of the environmental control of root elongation is, however, essential for forest management and for improving the efficiency of fertilization and irrigation in tree plantations. Seasonality in root elongation has been reported in a limited number of studies, and it was ascribed to the interaction of both endogenous and exogenous factors (Côté et al., 1998; Tierney et al., 2003). Soil temperature and soil water availability are among the exogenous factors that have been investigated more (Halter et al., 1996; Ni et al., 2000; Tierney et al., 2003). In temperate ecosystems, root elongation is minimal during winter because of unsuitable temperatures (Tierney et al., 2003) and sometimes a high water table. In addition, a decrease or even a halt in root elongation has been observed during the summer (Hendrick and Pregitzer, 1996; Joslin et al., 2001). A similar pattern has also been reported in tropical ecosystems exposed to a dry season, with higher elongation rates during the rainy season than during the dry season (Castellanos et al., 2001; Delitti et al., 2001; Green et al., 2005).

Fast-growing Eucalyptus genotypes have been extensively planted in the Tropics, mainly for pulpwood production. They are managed in short rotations, but the sustainability of these highly productive plantations is often questioned in resourcelimited environments, especially in areas characterized by soils with poor nutrient and water holding capacities and by a long dry season like the Kouilou Region in southern Congo. Up to now, studies of Eucalyptus root systems have involved a static description of root distribution and quantification of biomass (Bouillet et al., 2002; Laclau et al., 2001; Mello et al., 2007; Moroni et al., 2003; O'Grady et al., 2006; Saint-André et al., 2005; Stape et al., 2004). However, fewer investigations have been made of the environmental control of root dynamics (Fabião et al., 1985; Kätterer et al., 1995).
This study, conducted on two Eucalyptus stands in the Kouilou Region (Congo), set out to characterize seasonal variations in fine root (less than $2 \mathrm{~mm}$ in diameter) elongation using rhizotrons in the field. The choice of these two stands was based on previous studies showing that the installation phase ended 9 months after planting and that canopy closure occurred 2 years after planting. Our hypothesis was that seasonal variability in root elongation could be explained by seasonality of rainfall.

\section{MATERIAL AND METHODS}

\subsection{Site description}

This study was conducted in Congolese Eucalyptus plantations in the coastal plains of Pointe-Noire, Republic of Congo ( $4^{\circ} 02^{\prime} \mathrm{S}, 12^{\circ}$ 06 ' E) that are managed for pulpwood production. The climate is tropical and humid with an average annual rainfall of $1200 \mathrm{~mm}$ over the last 50 years and $1400 \mathrm{~mm}$ for the 1998-2003 period, with a rainy season from October to May and a marked dry season from June to September. The average annual temperature is $25^{\circ} \mathrm{C}$. Soils are deep ferralic aerosols (FAO classification) characterized by high sand (80$90 \%)$ and low clay $(8-10 \%)$ and silt $(2-2.5 \%)$ contents, with a very low cationic exchange capacity $\left(0.3-0.6 \mathrm{cmol}_{c} \mathrm{~kg}^{-1}\right.$ of soil) and a very low level of organic matter, even in the top soil, with a carbon content under $0.9 \%$ (Nzila et al., 2002). These soils lie over geological bedrock composed of thick detrital layers of continental origin dating from the Plio-Pleistocene (Jamet and Rieffel, 1976; Laclau et al., 2000). The native vegetation is a savannah dominated by the Poaceae Loudetia arundinacea (Hochst.) Steud.

The two experimental stands (9-month-old and 2-year-old at the beginning of the study) were located close to the village of Hinda. The two stands were $500 \mathrm{~m}$ apart. Both were in the second planting cycle. They were first planted on burned savannah, then coppiced and planted again after clear-cutting at a spacing of $3.2 \mathrm{~m} \times 3.8 \mathrm{~m}$ for the 9-month-old stand and at a spacing of $3.0 \mathrm{~m} \times 4.7 \mathrm{~m}$ for the 2-year-old stand (Epron et al., 2004; Saint-André et al., 2005). Both received starter fertilization (150 g of NPK 13-13-21 per tree) and herbaceous vegetation was chemically controlled. Table I gives the main characteristics of the two stands. The germplasm was Eucalyptus PF1, clone 1-41, which was produced by crossing E. alba and an unidentified Eucalyptus group containing E. robusta, E. grandis and E. botroïdes (see Bouillet et al., 2002, for details on this clone).

Clone PF1 1-41 is the most extensively planted in the area (16\% of total plantation area) and it is often used as a reference clone in many experimental plantations.

\subsection{Climate and soil water content}

Air temperature, soil temperature, rainfall and soil water content were measured in the 2-year-old stand. Air temperature was obtained 
from a weather station. Rainfall was measured using a tipping-bucket raingauge (ARG100; Environmental Measurements Ltd, Sunderland, UK). Soil water content was measured once a week with a timedomain reflectometer (TDR; Trase system, Soil Moisture, Santa Barbara, CA). Three series of seven TDR probes were installed horizontally in the soil at different depths $(0.15,0.5,1,1.5,3,4$ and $5 \mathrm{~m})$ according to Laclau et al. (2001). TDR probes were installed by digging 5-m deep trenches that were immediately refilled. Soil temperature was monitored at different depths by thermocouples buried at a depth of $0.01,0.02,0.04,0.08,0.30$ and $1 \mathrm{~m}$. The measurement period was $30 \mathrm{~s}$, averaged half-hourly using a data logger (CR10X, Campbell, Logan, USA). The data logger thermistor was used as a reference for the thermocouples. Monthly averages were calculated for temperature and soil water content, while rainfall was totalized for a given month.

\subsection{Rhizotron}

Three trees were chosen in different height classes in the 9-monthold stand where plant heights ranged between 0.8 and $1.5 \mathrm{~m}$ and four trees were chosen in different circumference at breast height $(\mathrm{CBH})$ classes in the 2-year-old stands where $\mathrm{CBH}$ values ranged between 15 and $40 \mathrm{~cm}$. Care was taken to select trees with straight boles in a clean area with no dead trees in their immediate vicinity. Fine root dynamics were monitored using rhizotrons (Jourdan and Rey, 1997; Green et al., 2005; Metcalfe et al., 2007; Sword, 1998). Square panes of glass $(0.9 \times 0.9 \mathrm{~m})$ were set up at a distance of about $1.5 \mathrm{~m}$ from the tree. Soil was evenly and gently compacted against the panes of glass. Two rhizotrons were installed around each tree: the first one in a near-vertical position was inclined from the vertical at an angle of $20^{\circ}$ and the second one in a near-horizontal position was inclined from the horizontal at an angle of $30^{\circ}$. The first rhizotron explored a soil depth of $0.85 \mathrm{~m}$ and the second a soil depth of $0.45 \mathrm{~m}$. We used this experimental design because fine root vertical distribution showed a decrease in root density with soil depth (Bouillet et al., 2002; Falkiner et al., 2006; Kätterer et al., 1995; Laclau et al., 2001; Mello et al., 2007). Vertical extension of the Eucalyptus root system in this region is very deep, with roots growing below $4 \mathrm{~m}$ nine months after planting (Thongo M'Bou, unpublished).

A transparent plastic sheet was attached to the left and right of the glass enabling the tracing of fine root segments with indelible multicoloured markers (a different colour for each sampling date). Each rhizotron window was covered with an opaque plastic film to shield roots from light, except during observation periods (Misra, 1999). Each trench was protected with a wooden roof to avoid solar radiation and inclement effects (high temperatures, rain, insect attacks, etc.). Thus, eight rhizotrons were set up in the 2-year-old stand and six in the 9-month-old stand. Root measurements started two weeks after rhizotron installation. In the two stands, rhizotrons were "refreshed" when they were fully covered with roots or when they were damaged by soil erosion. Refreshment consisted in cutting roots accumulated behind the glass and ensuring that the glass remained in contact with the soil. At the end of the study, or during refreshment periods, the glass was removed and roots growing on the rhizotron were collected. The basal diameter of each root was measured with a calliper. Few coarse roots ( $>2 \mathrm{~mm}$ in diameter) appeared on the rhizotron during the study in the two stands. They were subsequently excluded from the data analysis, which was performed on fine roots $(<2 \mathrm{~mm}$ in diameter) only.
The study was conducted between December 2000 and May 2002 and rhizotrons were monitored once a week from December 2000 to April 2001 and then twice a week from May 2001 to May 2002.

\subsection{Data analysis}

The observation sheets were manually digitized afterwards in the laboratory, on a $61 \mathrm{~cm} \times 91 \mathrm{~cm}$ format digitizer (Summagrid V, GTCO CalComp Inc., Columbia, MD, USA) which was operated by RhizoDigit software (CIRAD, Montpellier, France). That software enables semi-automatic acquisition of root data via the digitizer. RhizoDigit generates and manages a database that includes the appearance date of each root segment and its length at all observation dates. This information was then used to calculate the elongation rate of each root segment between two observation dates. The fine root elongation rate $\left(\mathrm{cm} \mathrm{d}^{-1}\right)$ was calculated by dividing the increase in length of a root segment between two observations by the number of days between those two observation dates. For each stand, elongation rates calculated on all rhizotrons were averaged on a monthly basis. Following rhizotron refreshment, the number of roots growing on the rhizotron windows was too low in April 2001 and between October 2001 and February 2002 in the 2-year-old stand to enable the calculation of fine root elongation rates. The monthly average fine root elongation rates in the two stands were compared using the non parametric Mann-Whitney U test at $p=0.05$.

\section{RESULTS}

2001 was an exceptionally dry year, with only $905 \mathrm{~mm}$ of rainfall, while annual precipitations averaged $1400 \mathrm{~mm}$ between 1998 and 2003, and the 2001 dry season was rather long, lasting from early June until November (Fig. 1A). In the 2year-old stand, there was no evidence of a larger seasonal variation in soil water content in shallow horizons than in deeper horizons (below $1 \mathrm{~m}$ ). Soil water content varied from $9.6 \%$ at $0.15 \mathrm{~m}$ and $8.9 \%$ at $0.5 \mathrm{~m}$ in February 2001 to $4.6 \%$ and $4.4 \%$ respectively in November (Fig. 1B). In the deeper soil horizon, the minimum soil water content was reached later in the dry season, and recovery during the following rainy season was also delayed. For instance, soil water content at a depth of $4 \mathrm{~m}$ ranged between $12.6 \%$ in January 2001 and $7.1 \%$ in January 2002. Soil temperature and air temperature exhibited a similar seasonal trend, with a well-known decrease during the dry season in southwest Congo because of continuous cloud cover which decreases incoming solar radiation (data not shown).

Monthly average fine (less than $2 \mathrm{~mm}$ in diameter) root elongation rates were not significantly different between the two stands, except in May 2002 (Mann-Whitney U test). Fine root elongation rates displayed a seasonal variation in the two stands with higher elongation rates during the rainy season than during the dry season (Fig. 2). Fine root elongation rates ranged from $0.40 \mathrm{~cm} \mathrm{~d}^{-1}$ in January 2001 to $0.22 \mathrm{~cm} \mathrm{~d}^{-1}$ in September in the 2-year-old stand. In the 9-month-old stand, maximum elongation rates occurred during the rainy season $\left(0.56 \mathrm{~cm} \mathrm{~d}^{-1}\right.$ in April 2001 and $0.45 \mathrm{~cm} \mathrm{~d}^{-1}$ in February 2002) and declined during the dry season until reaching the minimum value of $0.05 \mathrm{~cm} \mathrm{~d}^{-1}$ in November 2001. A considerable 

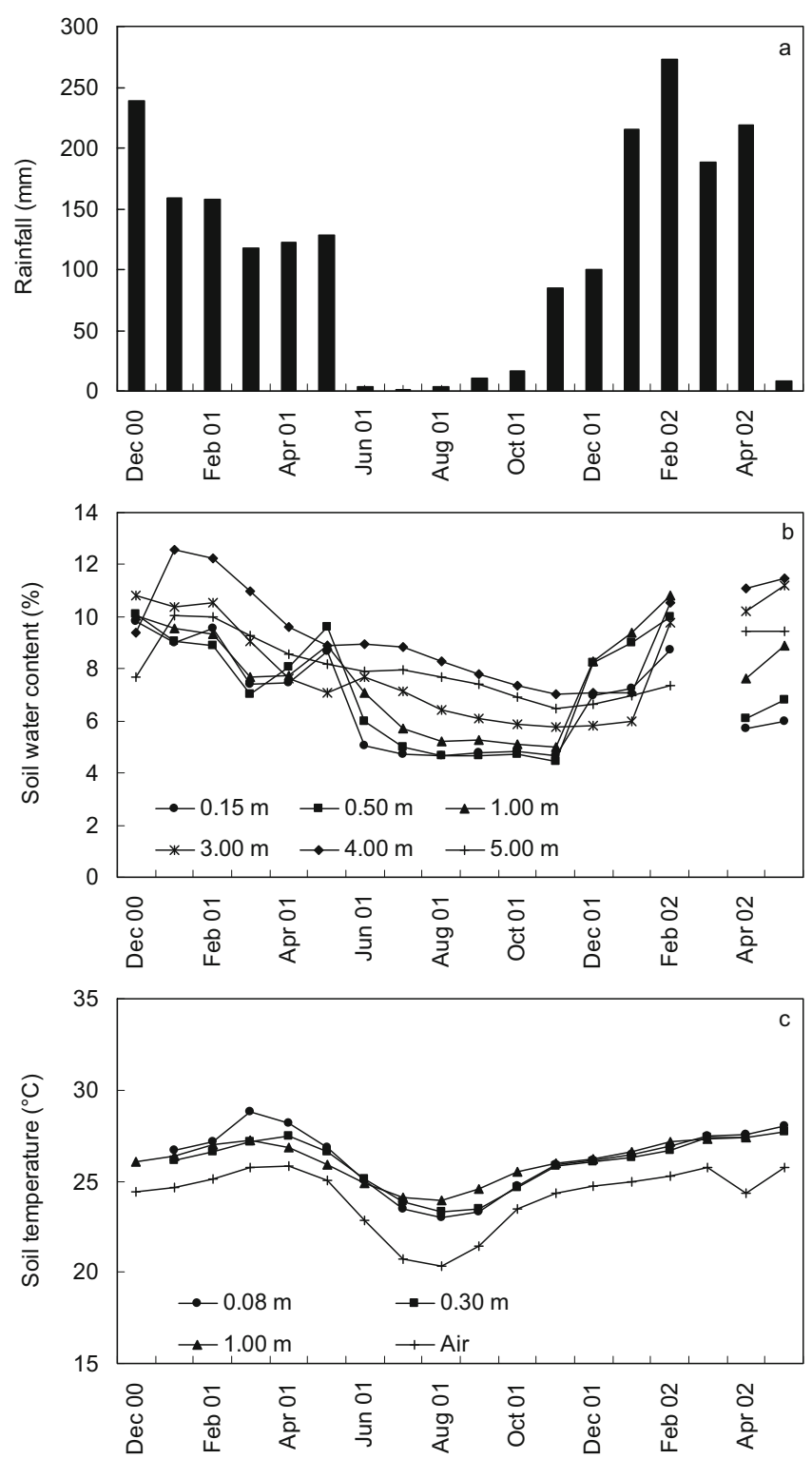

Figure 1. Seasonal monthly values of (a) rainfall, (b) average volumetric soil water content at six different depths, and (c) average air and soil temperatures at three different depths in the two-year-old stand over the study period.

resumption in the fine root elongation rate was observed at the beginning of the rainy season in December $2001\left(0.41 \mathrm{~cm} \mathrm{~d}^{-1}\right)$ after an unusually long dry season.

Positive and significant correlations were found between fine root elongation rates and soil water content at all depths in the 2-year-old stand. Better correlation coefficients were found with the soil water content of the deeper soil horizons ( $r=0.93$ with the soil water content measured at a depth of $4 \mathrm{~m}$, Fig. 3) than with the soil water content in the superficial soil horizons ( $r=0.73$ with the soil water content measured at a depth of $0.5 \mathrm{~m}$, for instance, see Tab. II). Fine root elongation rates were also positively and significantly correlated

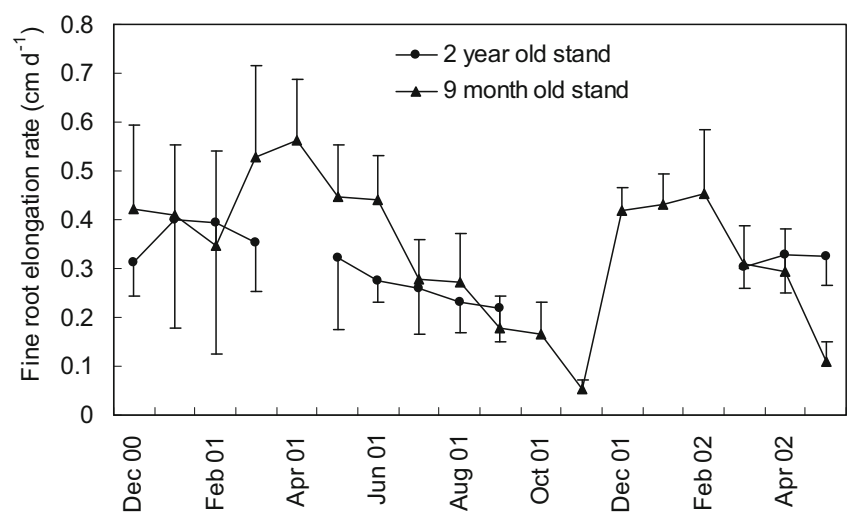

Figure 2. Seasonal monthly average root elongation rates in the ninemonth-old (eight rhizotrons) and in the two-year-old (six rhizotrons) stands. Vertical bars are confidence intervals at 0.05 .

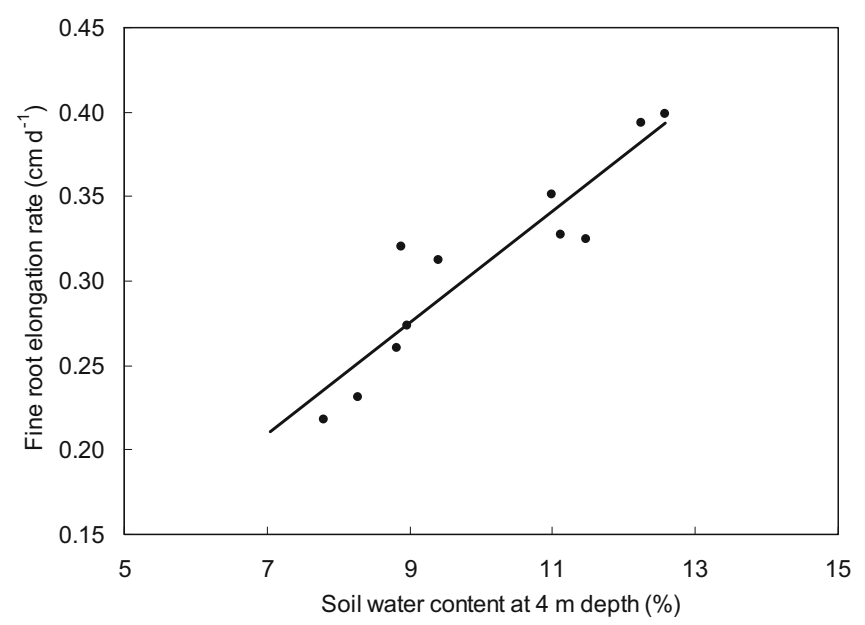

Figure 3. Relationship between the monthly average root elongation rate (eight rhizotrons) and soil water content at a depth of $4 \mathrm{~m}$ in the 2-year-old stand. The linear relationship was significant $(r=0.93)$.

with soil temperature at any depth, and with air temperature. The correlation was higher with air temperature $(r=0.79)$ and topsoil temperature $(r>0.80)$ than with deep soil temperature $(r=0.70$ at a depth of $1 \mathrm{~m}$, Tab. II). However, adding air temperature or superficial soil temperature as a second explanatory variable in a regression analysis did not improve the relation between the root elongation rate and the soil water content in the deep soil horizon, despite the lack of any significant correlation between air temperature and soil water content in the deep horizons.

\section{DISCUSSION}

The maximum fine root elongation rate recorded in this study $\left(0.56 \mathrm{~cm} \mathrm{~d}^{-1}\right.$ in the 9-month-old stand) was in the lower range of those reported for 4-month-old Eucalyptus seedlings grown under controlled conditions $\left(0.6\right.$ to $1.5 \mathrm{~cm} \mathrm{~d}^{-1}$ in E. nitens and 1 to $2 \mathrm{~cm} \mathrm{~d}^{-1}$ E. globulus, Misra, 1999), or for 
Table II. Correlation coefficients of relationships between fine root elongation rates (ER, 8 rhizotrons) and either soil water content (SWC) or air and soil temperature (T) at different depths in the soil in the two-year-old stand.

\begin{tabular}{cccc}
\hline \multicolumn{2}{c}{ ER versus SWC } & \multicolumn{2}{c}{ ER versus T } \\
\hline Depth $(\mathrm{m})$ & $r$ & Depth $(\mathrm{m})$ & $r$ \\
\hline 0.15 & 0.88 & Air & 0.79 \\
0.50 & 0.84 & 0.01 & 0.82 \\
1.00 & 0.92 & 0.02 & 0.83 \\
1.50 & 0.88 & 0.04 & 0.77 \\
3.00 & 0.83 & 0.08 & 0.80 \\
4.00 & 0.93 & 0.30 & 0.74 \\
5.00 & 0.94 & 1.00 & 0.70 \\
\hline
\end{tabular}

Quercus robur seedlings in a growth chamber $\left(1.4 \mathrm{~cm} \mathrm{~d}^{-1}\right.$, Epron et al., 1999).

Root cutting at both the installation and refreshment stages can bias the estimation of root elongation because of compensational growth (De Ruijter et al., 1996; Vogt et al., 1998). This is an inherent bias of the method leading to an overestimation of the fine root elongation rate. In some species, a certain period is required before the beginning of measurements (generally 3 months) to attain equilibrium in new root growth after rhizotron installation (Green et al., 2005; Metcalfe et al., 2007). In Eucalyptus however, a previous study of the effect of mechanical weeding on root development showed that few roots were formed at a wound (Bouillet et al., 1997). A careful examination behind the rhizotron windows at the end of the experiment did indeed reveal no reiteration at the cut end of roots severed during rhizotron installation, suggesting that most of the roots growing on the rhizotron were pre-existing roots that reached the rhizotron window after its installation or after refreshment. Lateral roots of Eucalyptus can extend considerably (up to $8 \mathrm{~m}$ in length in a one-year-old stand, unpublished data). Consequently, roots intercepted on a rhizotron come not only from the closest tree but also from all the trees in its vicinity.

The results of this study showed a seasonal trend in root elongation rates in the two stands. This appeared clearly in the 9-month-old stand for which the data set was complete. Fine roots grew continuously throughout the year, but with a seasonal trend characterized by a marked decrease at the end of the dry season. In the 9-month-old stand, the maximum fine root elongation rate in April was eleven times greater than the minimum reached in November. According to several investigations, endogenous or exogenous factors can contribute to the seasonal variation in root dynamics (Persson, 1983). In this study, soil water content was the main driver of fine root elongation. This was consistent with previous observations in tropical areas such as the Brazilian Cerrado (Delitti et al., 2001) or in a lowland dipterocarp forest in Sabah (Green et al., 2005), which linked fine root dynamics with rainfall and seasonal changes in soil water content. These results also agreed with those found for Mediterranean ecosystems (Lopez et al., 1998) or in a Eucalyptus globulus plantation in Portugal, where fine root growth in spring and summer was dependent on water supply (Kätterer et al., 1995). Our results contrasted with findings for temperate ecosystems, where fine root growth is strongly affected by soil temperature (Burke and Raynal, 1994). Root zone temperature is, indeed, thought to have a strong influence on fine root growth (Misra, 1999; Walter and Schurr, 2005). In this study, fine root elongation was more closely associated with soil water content than with soil temperature, probably because soil temperature remained high throughout the year $\left(26^{\circ} \mathrm{C}\right)$ and exhibited seasonal fluctuations of a narrow amplitude (less than $6{ }^{\circ} \mathrm{C}$ at a depth of $8 \mathrm{~cm})$.

Despite experimental evidence that the fine root growth rate is well related to soil water content and/or soil temperature, it is still a matter of controversy whether endogenous or exogenous factors control seasonal variations in root growth (Persson, 1983). Here, the strong correlation of the fine root elongation rate in the superficial soil horizons (between 0 and $0.85 \mathrm{~cm}$ ) with soil water content in deeper soil horizons suggested that root growth was much more related to the plant's water status than to the soil water content. The plant's water status would have depended on the soil water content in the soil horizons where roots took up water (i.e. in the deep soil horizons, at least during the dry season). This hypothesis is supported by a similar variation in soil water content in both the shallow and the deepest horizons ( 3 and $4 \mathrm{~m}$ deep). The plant's water status would have affected cell turgor. It has been shown that turgor pressure in the root tip controls root elongation in Eucalyptus pauciflora seedlings (Halter et al., 1996). However, cell elongation depends not only on turgor but also on cell wall properties that are known to be modulated by abscisic acid. Cell wall loosening, which is a prerequisite for cell elongation, is thought to be enhanced by abscisic acid (Wu et al., 1994) and it can counterbalance the decrease in cell turgor during drought. The relationship between root growth and cell turgor has been questioned (Tomos and Pritchard, 1994; Zhu and Boyer, 1992). An alternative explanation is that an alteration in plant water status, together with a lower air temperature and lower incoming solar radiation during the dry season due to a high cloud cover induced by the trade wind (Jamet and Riffel, 1976) and with seasonal leaf shedding (d'Annunzio, pers. comm.) will limit photosynthesis in trees and therefore the amount of carbon allocated belowground to support fine root growth. Fine root elongation of Eucalyptus in the field was probably regulated by photosynthate supply, as already suggested for Pinus sylvestris seedlings in boreal ecosystems (Livonen et al., 2001). Moreover, the competition for photosynthates between leaf and root growth may account for the delayed recovery in the root elongation rate at the beginning of the rainy season in November. Recovery of the leaf area index occurs rapidly at the beginning of the rainy season in Eucalyptus stands in this region (Nouvellon, unpublished data). A competition for photosynthate explained asynchronous growth rates between secondary root and leaves of Hevea brasiliensis seedlings (Thaler and Pagès, 1996). The difference in growth between roots and leaves was enhanced in shaded plants.

To conclude, fine root elongation in Eucalyptus exhibited a temporal variation that was related to the seasonality of rainfall, and was probably associated with seasonal changes in tree water status, carbon assimilation and belowground allocation. 
Acknowledgements: We thank Evariste Banguissa for technical assistance. This study was supported by 'ATP-carbone' (CIRAD project No. 2000/11).

\section{REFERENCES}

Bouillet J.P., Ognouabi N., and Bar-Hen A., 1997. Influence of soil preparation and weeding on the root development of a hybrid Eucalyptus in the Congo. In: Proc, IUFRO Conference on Sylviculture and Improvement of Eucalyptus, Salvador, Brazil, pp. 252-261.

Bouillet J.P., Laclau J.P., Arnaud M., Thongo-M'bou A., Saint-André L., and Jourdan C., 2002. Change with age in the spatial distribution of roots of Eucalyptus in Congo. Impact on water and nutrient uptake. For. Ecol. Manage. 171: 43-57.

Burke M.K. and Raynal D.J., 1994. Fine root growth phenology, production, and turnover in a northern hardwood forest ecosystem. Plant Soil 162: 135-146.

Castellanos J., Jaramillo V.J., Sanford R.L., and Kauffman J.B., 2001. Slash-and-burn effects on fine root biomass and productivity in a dry forest ecosystem in Mexico. For. Ecol. Manage. 148: 41-50.

Côté B., Hendershot W.H., Fyles J.W., Roy A.G., Bradley R., Biron P.M., and Courchesne F., 1998. The phenology of fine root growth in a maple-dominated ecosystem: relationships with some soil properties. Plant Soil 201: 59-69.

Delitti W.B.C., Pausas J.G., and Burger D.M., 2001. Belowground biomass seasonal variation in two neotropical savannahs (Brazilian Cerrados) with different fire histories. Ann. For. Sci. 58: 713-721.

De Ruijter F.J., Veen B.W., and Van Oijen M., 1996. A comparison of soil core sampling and minirhizotrons to quantify root development of field-grown potatoes. Plant Soil 182: 301-312.

Epron D., Toussaint M.L., and Badot P.M., 1999. Effects of sodium chloride salinity on root growth and respiration in oak seedlings. Ann. For. Sci. 56: 41-47.

Epron D., Nouvellon Y., Roupsard O., Mouvondy W., Mabiala A., SaintAndré L., Joffre R., Jourdan C., Bonnefond J. M., Berbigier P., and Hamel O., 2004. Spatial and temporal variations of soil respiration in a Eucalyptus plantation in Congo. For. Ecol. Manage. 202: 149-160.

Fabião A., Persson H.A., and Steen E., 1985. Growth dynamics of superficial roots in Portuguese plantations of Eucalyptus globulus Labill. studied with a mesh bag technique. Plant Soil 83: 233-242.

Falkiner R.A., Nambiar E.K.S., Polglase P.J., Theiveyanathan S., and Stewart L.G., 2006. Root distribution of Eucalyptus grandis and Corymbia maculata in degraded saline soils of south-eastern Australia. Agrofor. Syst. 67: 269-271.

Gill R.A. and Jackson R.B., 2000. Global patterns of root turnover for terrestrial ecosystems. New Phytol. 147: 13-31.

Green J., Dawson L., Proctor J., Duff E., and Elston D., 2005. Fine root dynamics in a tropical rain forest is influenced by rainfall. Plant Soil 276: $23-32$.

Halter R., Sands R., Nambiar E.K.S., and Ashton D.H., 1996. Elongation of Eucalyptus roots during day and night. Tree Physiol. 16: 877-881.

Hendrick R.L. and Pregitzer K.S., 1993. The dynamics of fine roots length, biomass and nitrogen content in two northern hardwood ecosystems. Can. J. For. Res. 23: 2507-2520.

Hendrick R.L. and Pregitzer K.S., 1996. Temporal and depth-related patterns of fine root dynamics in northern hardwood forests. J. Ecol. 84: $167-176$.
Hendricks J.J., Hendrick R.L., Wilson C.A., Mitchell R.J., Pecot S.D., and Guo D., 2006. Assessing the patterns and controls of fine root dynamics: an empirical test and methodological review. J. Ecol. 94: $40-57$.

Jamet R. and Rieffel J.M., 1976. Carte pédologique du Congo à 1/200.000, feuille Pointe-Noire, feuille Loubomo, notice d'exploitation n ${ }^{\circ} 65$, ORSTOM, Paris.

Joslin J.D., Wolfe M.H., and Hanson P.J., 2001. Factors controlling the timing of root elongation intensity in a mature upland oak stand. Plant Soil 228: 201-212.

Jourdan C. and Rey H., 1997. Architecture and development of the oilpalm (Elaeis guineensis Jacq.) root system. Plant Soil 189: 33-48.

Kätterer T., Fabião A., Madeira M., Ribeiro C., and Steen E., 1995. Fine-root dynamics, soil moisture and soil carbon content in a Eucalyptus globulus plantation under different irrigation and fertilisation regimes. For. Ecol. Manage. 74: 1-12.

Laclau J.P., Bouillet J.P., and Ranger J., 2000. Dynamics of biomass and nutrient accumulation in a clonal plantation of Eucalyptus in Congo. For. Ecol. Manage. 128: 181-196.

Laclau J.P., Arnaud M., Bouillet J.P., and Ranger J., 2001. Spatial distribution of Eucalyptus roots in a deep sandy soil in the Congo: relationships with the ability of the stand to take up water and nutrients. Tree Physiol. 21: 129-136.

Laclau J.P., Toutain F., Thongo M'bou A., Arnaud M., Joffre R., and Ranger J., 2004. The function of the superficial root mat in the biogeochemical cycles of nutrients in Congolese Eucalyptus plantations. Ann. Bot. 93: 249-261.

Lauenroth W.K. and Gill R., 2003. Turnover of root systems. In: de Kroon H., and Visser E.J.W. (Eds.), Root ecology, Springer, Berlin, Heidelberg, New York, 2003, pp. 61-89.

Livonen S., Rikala R., and Vapaavuori E., 2001. Seasonal root growth of Scots pine seedling in relation to shoot phenology, carbohydrate status, and nutrient supply. Can. J. For. Res. 31: 1569-1578.

Lopez B., Sabaté S., and Gracia C., 1998. Fine roots dynamics in a Mediterranean forest: effects of drought and stem density. Tree Physiol. 18: 601-606.

Majdi H., Pregitzer K., Moren A.S., Nylund J.E., and Ågren G.I., 2005. Measuring fine root turnover in forest ecosystems. Plant Soil 276: $1-8$.

Mello S.L.M., Gonçalves J.L.M., and Gava J.L., 2007. Pre- and postharvest fine root growth in Eucalyptus grandis stands installed in sandy and loamy soils. For. Ecol. Manage. 246: 146-195.

Metcalfe D.B., Meir P., and Williams M., 2007. A comparison of methods for converting rhizotron root length measurements into estimates of root mass production per unit ground area. Plant Soil 301: 279-288.

Misra R K., 1999. Root and shoot elongation of rhizotron-grown seedlings of Eucalyptus nitens and Eucalyptus globulus in relation to temperature. Plant Soil 206: 37-46.

Moroni M.T., Worledge D., and Beadle C.L., 2003. Root distribution of Eucalyptus nitens and E. globulus in irrigated and droughted soil. For. Ecol. Manage. 177: 399-407.

Neill C., 1992. Comparison of soil coring and ingrowth methods for measuring belowground production. Ecology 73: 1918-1921.

Ni J., Zang X.S., and Scurlock, J.M.O., 2001. Synthesis and analysis of biomass and net primary productivity in Chinese forests. Ann. For. Sci. 58: 351-384. 
Nzila J D., Bouillet J.P., Laclau J.P., and Ranger J., 2002. The effect of slash management on nutrient cycling and tree growth in Eucalyptus plantations in the Congo. For. Ecol. Manage. 171: 209-221.

O'Grady A.P., Worledge D., and Battaglia M., 2006. Above- and below-ground relationships, with particular reference to fine roots, in a young Eucalyptus globulus (Labill.) stand in southern Tasmania. Trees 20: 531-538.

Persson H.A., 1983. The distribution and productivity of fine root in boreal forests. Plant Soil 71: 87-101.

Saint-André L., Thongo M'Bou A., Mabiala A., Mouvondy W., Jourdan C., Roupsard O., Deleporte P., Hamel O., and Nouvellon Y., 2005. Age-related equations for above- and below-ground biomass of a Eucalyptus hybrid in Congo. For. Ecol. Manage. 205: 199-214.

Stape J.L., Binkley D., and Ryan M.G., 2004. Eucalyptus production and the supply, use and efficiency of use of water, light and nitrogen across a geographic gradient in Brazil. For. Ecol. Manage. 193: $17-31$.

Sword M.A., 1998. Seasonal development of loblolly pine lateral roots in response to stands density and fertilization. Plant Soil 200: 21-25.

Thaler P. and Pagès L., 1996. Root apical diameter and root elongation rate of rubber seedlings (Hevea brasiliensis) show parallel response to photoassimilate availability. Physiol. Plant. 97: 365-371.

Tierney G.L. and Fahey T.J., 2002. Fine root turnover in a northern hardwood forest: a direct comparison of the radiocarbon and minirhizotron methods. Can. J. For. Res. 32: 1692-1697.
Tierney G.L., Fahey T.J., Groffman P.M., Hardy J.P., Fitzhugh R.D., Driscoll C.T., and Yavitt J.B., 2003. Environmental control of fine root dynamics in a northern hardwood forest. Glob. Change. Biol. 9: 670-679.

Tomos D. and Pritchard J., 1994. Biophysical and biochemical control of cell expansion in roots and leaves. J. Exp. Bot. 45: 1721-1731.

Van Praag H.J., Sougnez-Remy S., Weissen F., and Carletti G., 1988. Root turnover in a beech and a spruce stand of the Belgian Ardennes. Plant Soil 105: 87-103.

Vogt K.A., Vogt D.J., and Bloomfield J., 1998. Analysis of some direct and indirect methods for estimating root biomass and production of forests at an ecosystem level. Plant Soil 200: 71-89.

Walter A. and Schurr U., 2005. Dynamics of leaf and root growth: Endogenous control versus environmental impact. Ann. Bot. 95: 891-900.

West J.B., Espeleta J.F., and Donovan L.A., 2004. Fine root production and turnover across a complex edaphic gradient of a Pinus palustris - Astrida savana ecosystem. For. Ecol. Manage. 189: 397-406.

Wu Y., Spollen W.G., Sharp R.E., Hetherington P.R., and Fry S.C., 1994. Root growth maintenance at low water potentials: increased activity of xyloglucan endotransglycosylase and its possible regulation by abscisic acid. Plant Physiol. 106: 607-615.

Zhu G.L. and Boyer J.S., 1992. Enlargement in Chara studied with a turgor clamp: Growth rate is not determined by turgor. Plant Physiol. 100: 2071-2080. 